Journal of The Indonesian Nutrition Association

p-ISSN: 0436-0265 e-ISSN: 2528-5874

http://ejournal.persagi.org/ojspersagi2481/index.php/Gizi_Indon

\title{
NUTRIMAT BAR MENURUNKAN SISA MAKANAN PASIEN KEMOTERAPI DI RSUP SANGLAH DENPASAR
}

\author{
Nutrimat Bar Decrease Food Waste of Chemotherapy Patients in The General Hospital \\ of Sanglah Denpasar
}

\author{
Ida Ayu Nyoman Triwini, Dylla Hanggaeni Dyah Puspaningrum, Ni Ketut Wiradnyani \\ Program Studi Ilmu Gizi, Universitas Dhyana Pura \\ E-mail: skrjgt@yahoo.com
}

\begin{abstract}
Chemotherapy is one of cancer medication methods by using cytotoxic medicines to eliminate cancer cells or to stop the growing of cancer cells. Side effect of chemotherapy medication are nausea and vomit that impact to the absorption of nutrition to the patients. Nutrimat bar is a food specially designed for chemotherapy patients in small size but contain high energy, protein and antioxidant. This study aimed to analyze of giving nutrimat bar todecrease food waste of chemotherapy patients in the general hospital of Sanglah Denpasar. Quasi experimental study using non-randomized pre and post-test with control group design was done on 33 patients using purposive sampling technique. The treatment done by giving nutrimat bar to the case group and hospital standard food to the controlled group. Measurement of food waste used visual comstock method. Data analysis used saphiro wilk test and independent t-test parametric test. The results showed that the average of food waste of chemotherapy patients in case group is $28,94 \%$ ( $\pm 8,50)$, while in the controlled group is $46,00 \%( \pm 4,70)$. The result of statistic examination indicated there are significant difference between food waste in case group and controlled group as much as $p<0,05$. It was concluded that nutrimat bar is effective to decrease food was towards chemotherapy patients in general hospital of Sanglah Denpasar.
\end{abstract}

Keywords: chemotherapy, food waste, nutrimat bar

\section{ABSTRAK}

Kemoterapi merupakan salah satu metode pengobatan kanker dengan obat-obatan sitostatika untuk menghancurkan sel kanker atau menghentikan perkembangan sel kanker. Efek samping dari pengobatan kemoterapi berupa mual dan muntah, sehingga dapat mempengaruhi asupan makan pasien. Nutrimat bar merupakan makanan khusus yang dirancang untuk pasien kemoterapi dengan ukuran kecil namun memiliki kandungan tinggi energi, protein dan antioksidan. Penelitian ini bertujuan untuk menganalisis pemberian nutrimat bar dalam menurunkan sisa makanan pasien kemoterapi di RSUP Sanglah Denpasar. Penelitian eksperimen semu dengan rancangan non-randommized pre and post test with control group disign ini dilakukan pada 33 orang pasien rawat inap dengan teknik purposive sampel. Perlakuan dilakukan dengan pemberian nutrimat bar pada kelompok kasus dan makanan standar rumah sakit pada kelompok kontrol. Pengukuran sisa makanan menggunakan metode visual comstock. Analisis data menggunakan uji normalitas saphiro wilk dan uji parametrik independent $t$-test. Hasil penelitian ini menunjukkan bahwa rata-rata sisa makanan pasien kemoterapi pada kelompok kasus sebesar $28,94 \%$ $( \pm 8,50)$, sedangkan pada kelompok kontrol sebesar $46,00 \%( \pm 4,70)$. Hasil uji statistik menunjukkan bahwa terdapat perbedaan yang signifikan antara sisa makanan pasien pada kelompok kasus dan kelompok kontrol dengan nilai $p<0,05$. Dapat disimpulkan bahwa nutrimat bar dapat menurunkan sisa makanan pasien kemoterapi di RSUP Sanglah Denpasar.

Kata kunci: kemoterapi, sisa makanan, nutrimat bar 


\section{PENDAHULUAN}

$\mathrm{K}$ emoterapi merupakan terapi penanganan kanker menggunakan pemberian segolongan obat-obatan sitostatika yang bertujuan menghambat pertumbuhan maupun membunuh sel kanker dengan menghentikan pembelahan selnya. ${ }^{1}$ Menurut data yang diperoleh dari rekam medis RSUP Sanglah Denpasar, diketahui bahwa pada tahun 2014 ada 500 pasien yang menjalani kemoterapi dan angka ini meningkat pada tahun 2015 sekitar 15 persen yaitu menjadi 575 pasien. $^{2}$

Pasien kemoterapi sering kali mengalami gangguan nutrisi akibat efek samping terapi yang digunakan, kurang lebih 30-87 persen pasien kanker mengalami malnutrisi pada saat menjalani terapi. Insiden malnutrisi tersebut bervariasi tergantung pada asal kanker, misalnya pada pasien dengan kanker pankreas dan gaster mengalami malnutrisi sampai 85 persen, 66 persen pada kanker paru dan 35 persen pada kanker payudara. ${ }^{3}$ Efek samping yang sering timbul pada pasien kemoterapi adalah mual muntah. Gangguan ini bervariasi tingkatannya, mulai dari yang ringan sampai kematian, akibat dehidrasi dan kurangnya asupan makanan. ${ }^{4}$ Penurunan nafsu makan (anoreksia) merupakan faktor utama terjadinya malnutrisi karena terjadinya hipermetabolisme pada pasien, dengan demikian perlu penanganan lebih lanjut pada pasien kemoterapi untuk dapat memperbaiki status gizinya secara optimal. ${ }^{5}$

Menurut laporan data SPMIN pada tahun 2015, mendapatkan hasil bahwa 75 persen pasien yang menjalani kemoterapi diruang rawat inap di RSUP Sanglah Denpasar tidak menghabiskan makanan yang disajikan dan $75 \%$ pasien mengeluhkan mutu makanan yang disajikan oleh rumah sakit. ${ }^{6} \mathrm{Hal}$ ini membuat pemenuhan kebutuhan gizi pasien tidak adekuat dan berujung pada malnutrisi di rumah sakit. Instalasi Gizi RSUP Sanglah Denpasar dalam melakukan perbaikan terhadap permasalahan tersebut membuat suatu inovasi pembuatan makanan, yaitu nutrimat bar. ${ }^{7}$

Nutrimat bar merupakan produk baru dan lebih menekankan pada kandungan antioksidan dengan memperkuat fungsional produk snack bar. Snack bar adalah makanan kecil lezat yang dibuat dari kacang-kacangan dan buah-buahan kering. ${ }^{8} \quad$ Snack bar kebanyakan tidak mengandung gluten dengan bahan penyusun mudah diolah dan dimodifikasi. ${ }^{9}$ Energi snack bar sangat sesuai dengan prinsip diet pasien kemoterapi yang memerlukan makanan dalam bentuk atau porsi kecil namun tinggi energi dan protein. ${ }^{10}$ Konsumsi akan snack bar di Indonesia masih sangat kecil dan hanya 34,5 persen masyarakat yang mengetahuinya, akan tetapi beberapa produsen makanan camilan sudah mulai memproduksi makanan tersebut sehingga banyak beredar diberbagai supermarket di Indonesia. ${ }^{11}$ Melihat potensi snack bar dalam pemenuhan gizi terutama pada pasien kemoterapi sangat baik untuk dikembangkan dan diterapkan, maka perlu dilakukan penelitian lebih mendalam mengenai manfaat snack bar dalam hal ini nutrimat bar dalam menurunkan sisa makanan pasien kemoterapi di RSUP Sanglah Denpasar.

\section{METODE PENELITIAN}

\section{Jenis Penelitian}

Penelitian ini bersifat eksperimen semu dengan non-randomized pre and post test with control group design, yaitu satu kelompok sampel mendapatkan perlakuan dan satu kelompok sampel sebagai kontrol. Perlakuan pada saat pre test: kelompok kasus dan kelompok kontrol sama-sama diberikan makanan standar rumah sakit dalam bentuk $3 \times 1$ porsi makan utama dan $2 \times 1$ porsi snack sesuai dengan menu yang disediakan oleh rumah sakit. Perlakuan pada saat post test yang diberikan berupa makanan standar rumah sakit, yaitu berupa $3 \times 1$ porsi makan utama dan $2 \times 1$ porsi snack bubur kacang ijo untuk kelompok kontrol dan berupa $3 \times 1$ porsi nutrimat bar, yaitu dua bungkus nutrimat bar dan $2 \times 1$ porsi snack bubur kacang ijo untuk kelompok kasus. Kandungan zat gizi dua bungkus nutrimat bar setara dengan satu porsi makanan utama standar rumah sakit, yaitu energi 551,7 kkal, protein 26,1 gram, lemak 15,9 gram dan karbohidrat 79,4 gram. Kedua kelompok sampel mendapatkan makanan dengan kandungan zat gizi yang sama, hanya bentuk makanan yang berbeda. Kerangka kerja penelitian dan contoh bentuk makanan utama standar rumah sakit dan nutrimat bar secara lengkap disajikan dalam Gambar 1 dan 2. Penelitian dilaksanakan di RSUP Sanglah Denpasar dari bulan Januari sampai Juli 2017. Penelitian ini telah 
mendapatkan persetujuan dari Komisi Etik Penelitian Kesehatan (KEPK) Fakultas Kedokteran Universitas Udayana dan RSUP Sanglah Denpasar dengan ethical clearance nomor 1029/UN.14.2/KEP/2017. Semua informasi dan data yang dikumpulkan dari subjek penelitian menggunakan informed consent dengan dijamin kerahasiaannya dan hanya digunakan untuk keperluan ilmiah.

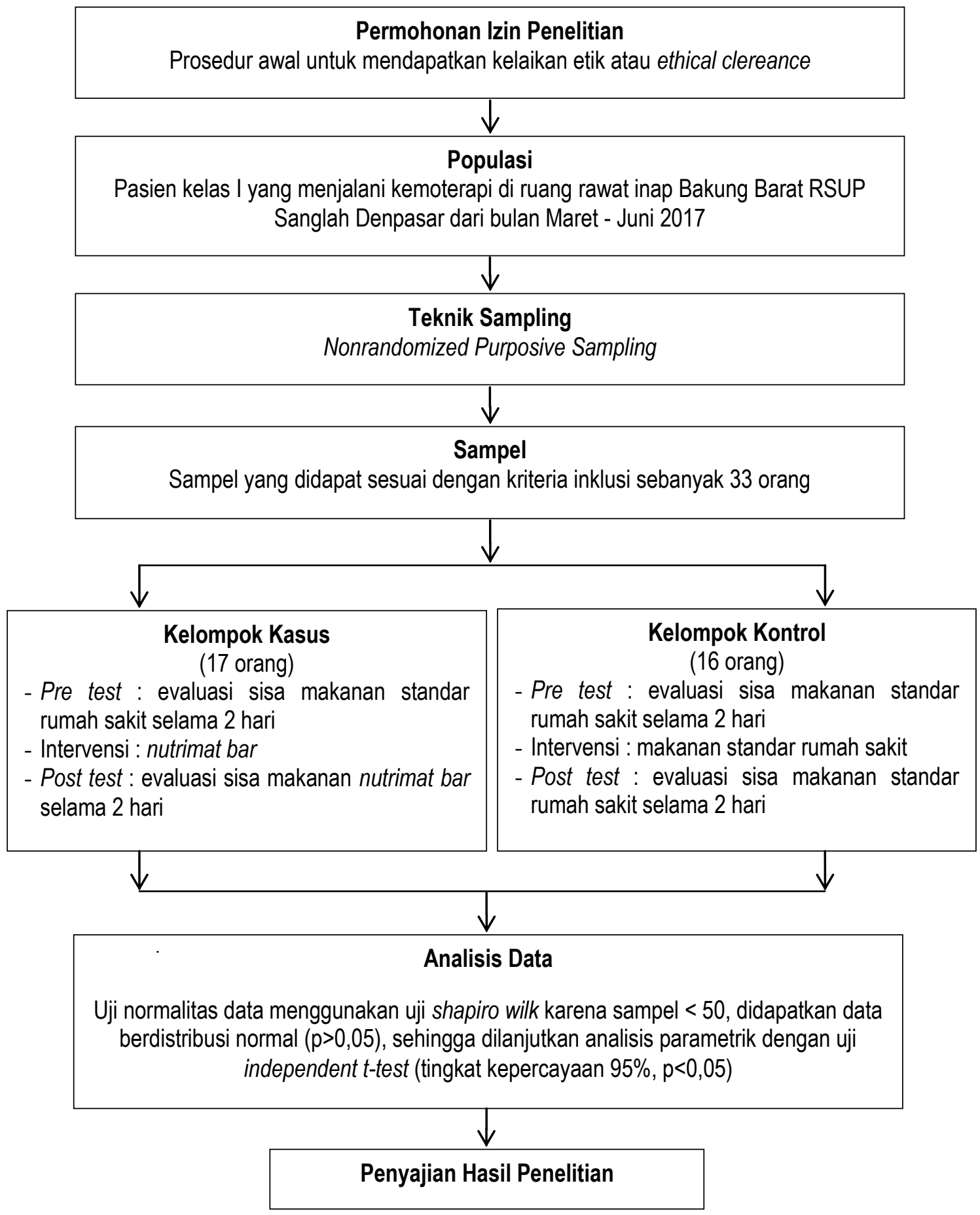

Gambar 1

Kerangka Kerja Penelitian 


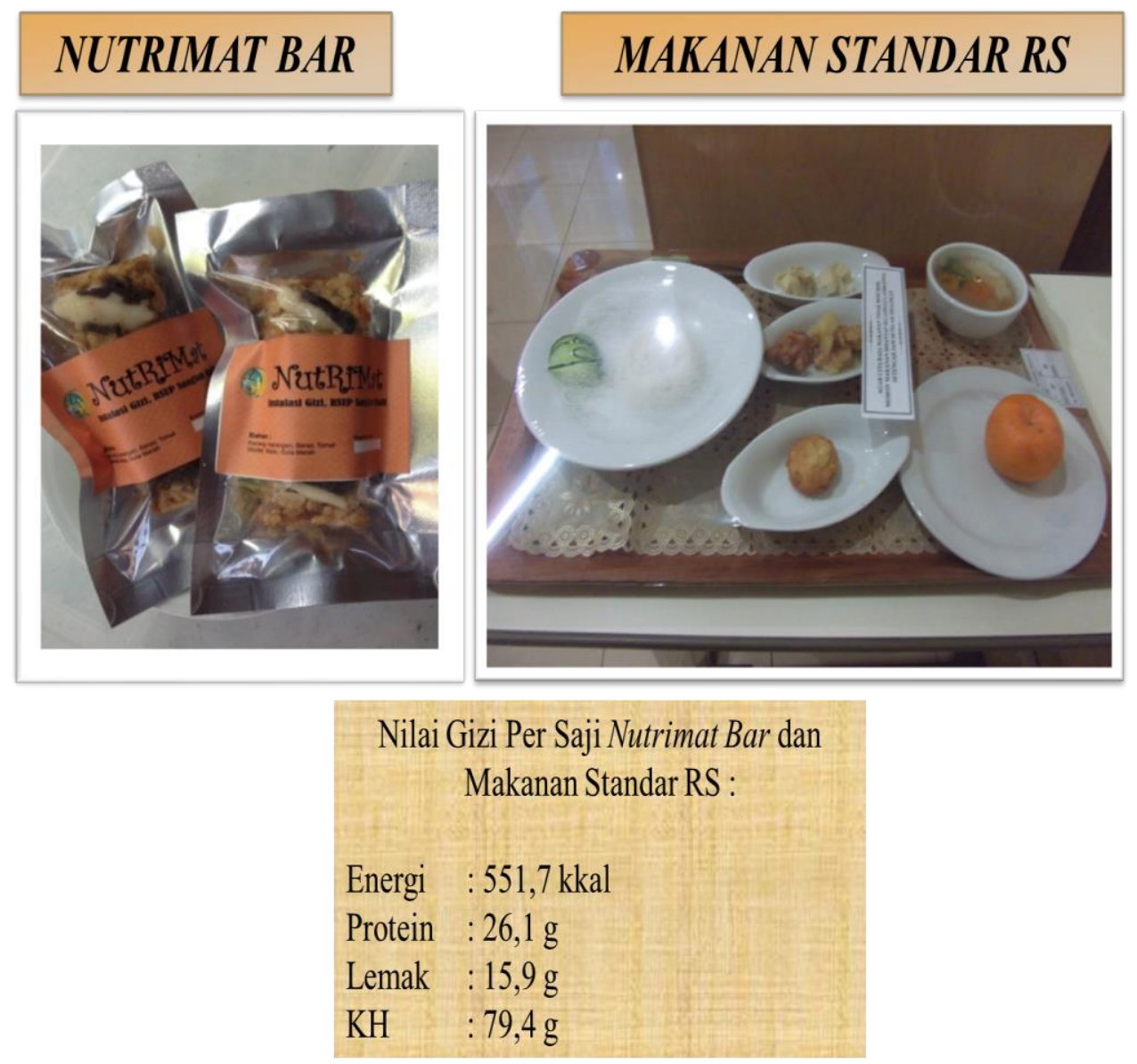

Gambar 2.

Bentuk Makanan Utama Standar Rumah Sakit dan Nutrimat Bar

\section{Subjek Penelitian}

Subjek penelitian ini adalah pasien kemoterapi yang di rawat inap di RSUP Sanglah Denpasar yang memenuhi kriteria inklusi antara lain pasien dewasa yang berumur 18-60 tahun; mendapatkan makanan per oral dengan bentuk makanan nasi; mempunyai kesadaran baik dan tidak mengalami kesulitan mengunyah atau menelan dan bersedia menjadi responden. Kriteria eksklusi yaitu pasien memiliki alergi terhadap beberapa bahan makanan, seperti : kacang-kacangan, telur atau susu. Subjek penelitian diambil menggunakan teknik purposive sampling sejumlah 33 orang, yaitu 17 orang kelompok kasus dan 16 orang kelompok kontrol. ${ }^{12}$

\section{Pengukuran Sisa Makanan}

Sisa makanan diukur menggunakan metode visual comstock dengan skala 6 poin selama empat hari, yaitu : dua hari sebelum (pre test) dan dua hari setelah (post test) perlakuan pada waktu makan pagi, siang, sore, snack pagi dan snack sore. Pengumpulan data dilakukan dengan cara observasi melibatkan tiga orang asisten peneliti (enumerator) dengan tingkat pendidikan S1 Gizi dan sebelumnya telah dilakukan diskusi dan penyamaan persepsi tentang cara pengambilan data sisa makanan pasien.

\section{Analisa Data}

Data hasil penelitian dianalisis meggunakan SPSS 16.0 for windows. Data jenis kelamin, umur, status gizi, kelompok penyakit, kelompok siklus kemoterapi dan sisa makanan subjek penelitian dianalisis secara deskriptif dan disajikan dalam bentuk tabel. Uji normalitas data menggunakan uji Saphiro wilk, dengan nilai $p>0,05$ sebaran data normal. Data presentase sisa makanan sebelum (pre test) dan sesudah (post test) perlakuan, baik pada 
kelompok kasus dan kelompok kontrol dianalisis menggunakan uji parametrik Independent $t$-test dengan tingkat kepercayaan 95 persen $(p<0,05)$.

\section{HASIL}

\section{Karakteristik Subjek Penelitian}

Karakteristik subjek dalam penelitian ini, meliputi: jenis kelamin, umur, status gizi, kelompok penyakit dan kelompok siklus kemoterapi. Hasil penelitian menunjukkan bahwa sebagian besar pasien berjenis kelamin perempuan $(54,5 \%)$, dengan kisaran umur 45 54 tahun, memiliki status gizi baik sebanyak 78,9 persen. Distribusi kelompok penyakit terbanyak pada perempuan adalah kanker serviks $(21,2 \%)$, sedangkan pada laki-laki adalah kanker testis (18,2\%), dengan sebagian besar menjalani siklus kemoterapi seri II $(45,5 \%)$. Karakteristik subjek penelitian secara lengkap disajikan dalam Tabel 1.

\section{Hasil Analisis Sisa Makanan Pasien Sebelum Perlakuan (Pre Test)}

Hasil analisis menunjukkan bahwa rata-rata sisa makanan pasien pada kelompok kasus 52,52 persen $( \pm 15,58)$ dan pada kelompok kontrol 45,93 persen $( \pm 4,35)$. Hasil analisis statistik menunjukkan bahwa nilai $p>0,05$ yang artinya sisa makanan pasien pada kedua kelompok penelitian sebelum perlakuan (pre test) tidak berbeda bermakna. Hasil analisis secara lengkap disajikan pada Tabel 2.

Tabel 1

Karakteristik Subjek Penelitian

\begin{tabular}{|c|c|c|c|c|c|c|}
\hline \multirow{3}{*}{ Variabel } & \multicolumn{4}{|c|}{ Kelompok } & \multirow{2}{*}{\multicolumn{2}{|c|}{ Total }} \\
\hline & \multicolumn{2}{|c|}{ Kasus } & \multicolumn{2}{|c|}{ Kontrol } & & \\
\hline & Jumlah & $\%$ & Jumlah & $\%$ & Jumlah & $\%$ \\
\hline \multicolumn{7}{|l|}{ Jenis kelamin } \\
\hline Laki-laki & 9 & 27,3 & 6 & 18,2 & 15 & 45,5 \\
\hline Perempuan & 8 & 24,2 & 10 & 30,3 & 18 & 54,5 \\
\hline \multicolumn{7}{|c|}{ Kelompok umur (tahun) } \\
\hline $25-34$ & 4 & 12,1 & 3 & 9,1 & 7 & 21,2 \\
\hline $35-44$ & 3 & 9,1 & 2 & 6,1 & 5 & 15,2 \\
\hline $45-54$ & 7 & 21,2 & 9 & 27,2 & 16 & 48,4 \\
\hline $55-64$ & 3 & 9,1 & 2 & 6,1 & 5 & 15,2 \\
\hline \multicolumn{7}{|c|}{ Kelompok status gizi } \\
\hline Kurang & 4 & 12,1 & 1 & 3,0 & 5 & 15,1 \\
\hline Baik & 12 & 36,5 & 14 & 42,4 & 26 & 78,9 \\
\hline Lebih & 1 & 3,0 & 1 & 3,0 & 2 & 6,0 \\
\hline \multicolumn{7}{|l|}{ Kelompok penyakit } \\
\hline Ca. Recti & 3 & 9,1 & 3 & 9,1 & 6 & 18,2 \\
\hline Ca. Testis & 4 & 12,1 & 2 & 6,1 & 6 & 18,2 \\
\hline Ca. Mandibula & 2 & 6,1 & 3 & 9,1 & 5 & 15,2 \\
\hline Ca. Mamae & 1 & 3,0 & 2 & 6,1 & 3 & 9,1 \\
\hline Ca. Cerviks & 5 & 15,2 & 2 & 6,1 & 7 & 21,2 \\
\hline AML & 1 & 3,0 & 3 & 9,1 & 4 & 12,1 \\
\hline CBD Stone & 1 & 3,0 & 1 & 3,0 & 2 & 6,0 \\
\hline \multicolumn{7}{|l|}{ Siklus kemoterapi } \\
\hline Seri I & 2 & 6,1 & 1 & 3,0 & 3 & 9,1 \\
\hline Seri II & 6 & 18,2 & 9 & 27,3 & 15 & 45,5 \\
\hline Seri III & 6 & 18,2 & 4 & 12,1 & 10 & 30,3 \\
\hline Seri IV & 3 & 9,1 & 2 & 6,0 & 5 & 15,1 \\
\hline
\end{tabular}


Tabel 2.

Hasil Analisis Sisa Makanan Pre dan Post Test

\begin{tabular}{cccc}
\hline \multirow{2}{*}{ Variabel } & \multirow{2}{*}{ Jumlah } & Sisa makanan $(\%)$ & \multirow{2}{*}{ Nilai $p$} \\
\cline { 3 - 3 } & & Mean \pm SD & \\
Pre Test & 17 & $52,52 \pm 15,58$ & \multirow{2}{*}{0,110} \\
Kasus & 16 & $45,93 \pm 4,35$ & \\
Kontrol & & & \\
Post Test & 17 & $5,76 \pm 4,04$ & 0 \\
$\quad$ Kasus & 16 & $46,12 \pm 5,73$ & 0,000 \\
Kontrol & Keterangan : $\mathrm{p}=$ hasil analisis statistik parametrik independent t-test &
\end{tabular}

Tabel 3

Hasil Efektifitas Pemberian Nutrimat Bar

\begin{tabular}{|c|c|c|c|}
\hline \multirow{2}{*}{ Variabel } & \multirow{2}{*}{ Jumlah } & Sisa makanan (\%) & \multirow{2}{*}{ Nilai $p$} \\
\hline & & Mean \pm SD & \\
\hline \multicolumn{4}{|l|}{ Kasus } \\
\hline Pre test & 17 & $52,52 \pm 15,58$ & \multirow{3}{*}{0,000} \\
\hline Post test & 17 & $5,76 \pm 4,04$ & \\
\hline Kontrol & & & \\
\hline Pre test & 16 & $45,93 \pm 4,35$ & \multirow{3}{*}{0,918} \\
\hline Post test & 16 & $46,12 \pm 5,72$ & \\
\hline Perlakuan & & & \\
\hline Nutrimat Bar & 17 & $28,94 \pm 8,50$ & \multirow{2}{*}{0,000} \\
\hline Makanan Standar RS & 16 & $46,00 \pm 4,70$ & \\
\hline
\end{tabular}

Keterangan : $p=$ hasil analisis statistik parametrik independent $t$-test

\section{Hasil Analisis Sisa Makanan Pasien Sesetelah Perlakuan (Post Test)}

Hasil analisis menunjukkan bahwa rata-rata sisa makanan pasien pada kelompok kasus 5,76 persen $( \pm 4,04)$ dan pada kelompok kontrol 46,12 persen $( \pm 5,73)$. Hasil analisis statistik menunjukkan bahwa nilai $p<0,05$ yang artinya sisa makanan pasien pada kedua kelompok penelitian setelah perlakuan (post test) berbeda bermakna. Secara lengkap hasil analisis disajikan dalam Tabel 2.

\section{Hasil Analisis Efektifitas Pemberian Nutrimat Bar}

Hasil analisis menunjukkan bahwa terdapat perbedaan sisa makanan pasien pada kelompok kasus yang mendapatkan nutrimat bar sebelum (pre test) dan sesudah (post test) perlakuan dengan nilai $p<0,05$, sedangkan pada kelompok kontrol yang mendapatkan makanan standar rumah sakit sebelum (pre test) dan sesudah (post test) perlakuan tidak terdapat perbedaan sisa makanan pasien dengan nilai $p>0,05$. Efektifitas pemberian nutrimat bar dapat diketahui dari hasil uji statistik menggunakan uji parametrik independent sampel t-test menunjukkan nilai $p$ value $=0,000<a=0,05$ maka $\mathrm{H}_{0}$ ditolak, yang artinya ada berbedaan sisa makanan antara kelompok kasus (diberikan nutrimat bar) dengan kelompok kontrol (diberikan makanan standar rumah sakit) pada pasien kemoterapi di RSUP Sanglah Denpasar. Hal ini menunjukkan bahwa nutrimat bar dapat menurunkan sisa makanan pasien kemoterapi di RSUP Sanglah Denpasar, yang sebelumnya sisa makanan pasien sebesar 52,52 persen menjadi 5,76 persen. Hasil analisis secara lengkap disajikan Tabel 3.

\section{BAHASAN}

\section{Karakteristik Subjek Penelitian}

Hasil penelitian ini menunjukkan bahwa sebagian besar subjek penelitian berjenis kelamin perempuan. Data ini sejalan dengan hasil penelitian pada tahun 2015 di RSUD Arifin Achmad, Riau, yang menunjukkan bahwa sebagian besar penderita kanker berjenis 
kelamin perempuan yaitu 78,4 persen. Prevalensi kanker pada perempuan cenderung lebih tinggi dibandingkan laki-laki, dikarenakan pada perempuan biasanya lebih peduli terhadap kesehatannya dibandingkan laki-laki, sehingga kasus kanker atau tumor dapat terdeteksi lebih banyak pada perempuan dibandingkan lakilaki. $^{5}$

Karakteristik umur subjek penelitian sebagian besar terletak antara umur 45-54 tahun, dengan rata-rata umur $44,36( \pm 9,68)$ tahun, umur termuda 25 tahun dan umur tertua 60 tahun. Hasil penelitian ini sejalan dengan penelitian pada tahun 2012 tentang Pengaruh Kombinasi Vitamin C dan E Dosis Tinggi Terhadap Sistem Hemopoetik Penderita Kanker, yang menunjukkan bahwa rata-rata umur subjek penelitian 47,2 tahun dengan umur termuda 18 tahun dan tertua 68 tahun. Penyebab terjadinya kanker adalah multifaktor, dapat terjadi karena paparan zat karsinogenik yang terakumulasi menyebabkan kelainan gen bertransformasi ke arah sel kanker. Proses ini membutuhkan waktu berpuluh tahun sehingga frekuensi kanker meningkat seiring bertambahnya usia. ${ }^{13}$

Indeks Masa Tubuh (IMT) dapat digunakan untuk menentukan status gizi sesorang dengan cara mengukur berat badan (BB) dan tinggi badan (TB) orang dewasa yang berada pada rentang umur 19 - 70 tahun. ${ }^{5}$ Hasil data status gizi sebagian besar subjek penelitian berstatus gizi baik, hanya sebagian kecil berstatus gizi lebih. Hasil penelitian ini sejalan dengan penelitian pada tahun 2010 di RSUP Dr.Kariadi, Semarang, yang menyatakan bahwa tidak terdapat perubahan yang bermakna antara IMT sebelum dan sesudah terapi dengan didapatkan IMT pasien kemoterapi mayoritas IMT normal. Hal ini dapat disebabkan oleh beberapa faktor, seperti: belum terjadi reaksi efek samping terapi yang cukup ekstrim, penggunaan obat yang tepat, perlakuan masukan asupan gizi optimal, status gizi pada awal terapi masih dalam kategori baik dan periode waktu yang masih pendek dalam pemberian terapi. ${ }^{14}$

Distribusi kelompok penyakit terbanyak ada pada penyakit kanker serviks 7 orang $(21,2 \%)$ dan terkecil ada pada penyakit kanker tulang 2 orang $(6,1 \%)$. Hasil penelitian ini sejalan dengan penelitian pada tahun 2012 di RSUP Dr.Kariadi, Semarang yang menyatakan bahwa penderita kanker serviks paling banyak ditemui pada stadium III B $(78,1 \%) .{ }^{15}$ Hasil ini didukung data Kemenkes RI pada tahun 2014, yang menunjukkan bahwa jenis kanker yang paling banyak terjadi di Indonesia adalah kanker payudara dan kanker serviks pada perempuan, sedangkan pada laki-laki jenis kanker tertinggi adalah kanker paru-paru dan kanker kolorektal. ${ }^{16}$

Karakteristik kelompok siklus kemoterapi dapat diketahui bahwa subjek penelitian sebagian besar 15 orang $(45,5 \%)$ berada pada siklus kemoterapi seri II, hanya sebagian kecil 3 orang $(9,1 \%)$ berada pada siklus kemoterapi seri I. Hasil ini sejalan dengan penelitian pada tahun 2015 di RSUD Arifin Achmad, Riau, yang mengatakan bahwa karakteristik siklus kemoterapi mayoritas seri II sebanyak 41 orang $(80,4 \%)$. Kemoterapi seri I dan II merupakan tahap awal dari pengobatan kemoterapi yang dimulai dari siklus ke 1 dan berakhir pada siklus ke 6, sehingga gejala kemoterapi seperti mual, muntah dan tidak ada nafsu makan (anoreksia) belum muncul. ${ }^{17}$ Hasil penelitian ini tidak sejalan dengan penelitian pada tahun 2012 di rumah sakit Singapura, yang menyatakan bahwa prevalensi risiko kejadian malnutrisi sebanyak 45 persen terjadi pada pasien kanker yang menjalani siklus pertama kemoterapi. Pasien yang menerima tiga kali siklus kemoterapi pertama (seri I) lebih berisiko terkena kejadian malnutrisi dari pada yang menerima tujuh kali siklus atau lebih (seri III keatas). ${ }^{18}$

\section{Hasil Analisis Sisa Makanan Pasien Sebelum Perlakuan (Pre Test)}

Kelompok kasus dan kelompok kontrol pada saat pre test sama-sama mendapatkan makanan utama berupa makanan standar rumah sakit. Hasil analisis statistik menunjukkan bahwa nilai $p>0,05$ yang artinya sisa makanan pasien pada kedua kelompok penelitian sebelum perlakuan tidak berbeda bermakna. Hasil penelitian ini sejalan dengan penelitian pada tahun 2014 dilakukan di Universitas Diponegoro, Semarang, yang menyatakan bahwa tidak terdapat pengaruh yang signifikan pada kedua kelompok penelitian sebelum pemberian snack bar ubi jalar kedelai hitam terhadap asupan makan. ${ }^{19}$ Faktor penyebab pasien menyisakan makanan dapat dipicu oleh rasa mual muntah pada saat pasien mencium aroma masakan dari rumah sakit, makanan yang berlemak, makanan dan minuman yang 
manis, bau yang menyengat, makanan dengan tekstur yang basah dan makanan yang berbau amis. ${ }^{20}$ Mual dan muntah dapat dirangsang oleh bau, selera, pikiran dan kecemasan terkait kemoterapi. Upaya untuk mengatasi rasa mual dan muntah dapat dilakukan dengan mengkonsumsi makanan yang kering dan segar dalam porsi kecil tapi sering, menghindari makanan yang berbau merangsang, berlemak tinggi serta makanan yang terlalu manis. ${ }^{21}$

\section{Hasil Analisis Sisa Makanan Pasien Sesetelah Perlakuan (Post Test)}

Kedua kelompok penelitian pada saat post test mendapatkan makanan yang berbeda, yaitu makanan utama berupa makanan standar rumah sakit untuk kelompok kontrol dan makanan utama berupa nutrimat bar untuk kelompok kasus. Hasil analisis statistik menunjukkan bahwa nilai $p<0,05$ yang artinya sisa makanan pasien pada kedua kelompok penelitian setelah perlakuan berbeda bermakna. Hasil penelitian ini sejalan dengan penelitian pada tahun 2014 dilakukan di Universitas Diponegoro, Semarang, yang menyatakan bahwa terdapat pengaruh yang signifikan pada kedua kelompok penelitian setelah pemberian snack bar ubi jalar kedelai hitam terhadap asupan makan. ${ }^{19}$ Peningkatan asupan makanan dapat dipengaruhi oleh rasa dan penampilan makanan. Pasien yang menyatakan rasa dan penampilan makanan baik cenderung menyisakan makanan lebih sedikit. ${ }^{22} \mathrm{Hal}$ serupa juga dilaporkan pada penelitian tahun 2008 dilakukan di RS Bhakti Wira Tamtama Semarang, yang menyatakan bahwa penggunaan dan pemilihan alat makan yang tepat dalam penyusunan makanan akan mempengaruhi penampilan makanan yang disajikan, semakin tidak menarik penampilan makanan akan semakin banyak pasien menyisakan makanan. ${ }^{23}$ Food bars dapat memenuhi permintaan konsumen akan gizi, praktis, rasa, penampilan serta dapat mengurangi rasa lapar dalam waktu yang singkat.24 Food bars dapat mencukupi kebutuhan kalori rata-rata orang dewasa per hari yakni energi 2100 kkal dengan kandungan protein 7-12 persen dari total kalori dan lemak $35-45$ persen..$^{25}$

\section{Hasil Analisis Efektifitas Pemberian Nutrimat Bar}

Hasil pengukuran pada kedua kelompok penelitian (kasus dan kontrol) terhadap sisa makanan pasien sebelum (pre test) dan sesudah (post test) perlakuan menunjukkan bahwa nutrimat bar dapat menurunkan sisa makanan pasien kemoterapi, yang sebelumnya sisa makanan pasien sebesar 52,52 persen menjadi 5,76 persen. Hal ini dapat terjadi karena nutrimat bar memiliki ukuran yang kecil namun tinggi energi, protein dan antioksidan, sehingga tepat diberikan untuk pasien kanker yang memerlukan makanan porsi kecil tapi sering. ${ }^{26}$ Hasil wawancara langsung kepada pasien diketahui bahwa nutrimat bar lebih disukai atau memiliki tingkat penerimaan yang lebih baik dibandingkan makanan standar rumah sakit, karena: (1) rasa makanan enak, tekstur lembut dan tidak beraroma yang dapat merangsang mual, (2) makanan dalam porsi kecil tapi kaya nutrisi, sehingga bisa mencukupi kebutuhan nutrisi pasien dan (3) makanan dapat dimakan setiap saat dalam porsi kecil tapi sering. Hasil penelitian ini sejalan dengan penelitian pada tahun 2014 di RSUD Sunan Kalijaga, Demak, yang menunjukkan bahwa terdapat perbedaan sisa makanan kelompok menu pilihan dan kelompok menu standar secara bermakna dengan $p$-value 0,000 . Hasil ini sesuai dengan teori yang menjelaskan bahwa daya terima terhadap suatu makanan ditentukan oleh rangsangan dari indera penglihatan, penciuman, pencicip dan pendengaran. ${ }^{27}$ Faktor utama yang dinilai dari cita rasa diantaranya adalah rupa yang meliputi warna, bentuk, ukuran, aroma, tekstur dan rasa. Pemilihan menu yang sesuai dengan keinginan akan membuat seseorang lebih tertarik menghabiskan makanan dan berusaha tidak meninggalkan sisa, sehingga asupan makanan yang ditentukan akan lebih mudah terpenuhi dengan adanya pemilihan menu sesuai dengan keinginan pasien. $^{28}$ Pendapat tersebut mendukung hasil penelitian kali ini yang menunjukkan bahwa dengan diberikan makanan pilihan atau makanan alternatif yaitu nutrimat bar dapat efektif mengurangi sisa makanan pasien kemoterapi di RSUP Sanglah Denpasar. 


\section{SIMPULAN DAN SARAN}

\section{Simpulan}

Nutrimat bar dapat menurunkan sisa makanan pasien kemoterapi di RSUP Sanglah Denpasar yang sebelumnya 52,52 persen menjadi 5,76 persen

\section{Saran}

Penelitian yang akan datang hendaknya dapat mengukur daya terima nutrimat bar terhadap peningkatan berat badan dan status gizi pasien, tidak terbatas hanya pada pasien kemoterapi tapi juga pada pasien lain yang memiliki asupan makanan kurang.

\section{UCAPAN TERIMA KASIH}

Ucapan terima kasih penulis sampaikan kepada Direktur RSUP Sanglah Denpasar yang telah memberikan izin penelitian sehingga penelitian ini terselenggara. Ucapan terima kasih juga disampaikan kepada Kepala Instalasi Gizi RSUP Sanglah Denpasar yang telah membantu dalam proses pelaksanaan penelitian serta kepada pasien rawat inap yang telah bersedia menjadi responden dan berpartisipasi dalam penelitian ini.

\section{RUJUKAN}

1. Bowden VR, Dickey S, Greenberg CS. Children and their families the continuum of care. Philadelphia: Saunders Company; 2010.

2. Instalasi Rekam Medis RSUP Sanglah. Data Pasien Kemoterapi. Denpasar: RSUP Sanglah. 2015.

3. Sutandyo N. Nutrisi pada pasien kanker yang mendapat kemoterapi. Indonesian Journal of Cancer. 2007; 4:144-148.

4. Rahmah DS. Evaluasi penggunaan obat antimuntah pada pasien retinoblastoma anak yang menjalani kemoterapi di Rumah Sakit Kanker Dharmais. Indonesian Journal of Cancer. 2009; 3(1):1-4

5. Hardiano R, Nurul H, Jumaini. Gambaran indeks massa tubuh pada pasien kanker yang mengalami kemoterapi. JOM. 2015; 2 (2): 1381-1388.

6. Instalasi Gizi RSUP Sanglah. Laporan Tahunan Instalasi Gizi. Denpasar: RSUP Sanglah. 2015.
7. GKM Mekar Bersemi Instalasi Gizi RSUP Sanglah. Laporan Tahunan "Mengurangi Sisa Makanan Pasien Kemoterapi". Denpasar. GKM Mekar Bersemi Instalasi Gizi RSUP Sanglah. 2016.

8. Skolnik $\mathrm{H}$, Chernus A. Nutrient timing for peak performance (The Rights Food, The Rights Time, The Rights Results) [Online]. Human Kinetics. 2010. ISBN 0736087648, 9780736087643[cited 2017 Peb 13]. Available from: http://www.humankinetics.com/products/all -products/nutrient-timing-for-peakperformance-ebook.

9. Pradipta I. Karakteristik fisikokimia dan sensori snack bar tempe dengan penambahan salak pondok kering. Skripsi. Surakarta: Universitas Sebelas Maret. 2011.

10. Hudayani F. Gangguan makan pasca kemoterapi dan radiasi [Online]. 2012 [cited 2017 Peb 13]. p, 1-3 Available from : http://gizi.depkes.go.id/wpcontent/uploads/2012/05/Ganggn-mknpasca-kemotrp.pdf.

11. Hakim VR, Fitriyono. Analisis aktivitas antioksidan, kandungan zat gizi makro dan mikro snack bar beras warna sebagai makanan selingan penderita nefropati diabetik. Journal of Nutrition College. 2013; 2(4):431-438

12. Saryono, Anggreni. Metodologi Penelitian Kualitatif dan Kuantitatif Dalam Bidang Kesehatan. Jakarta: Nuha Medika. 2013.

13. Aminullah $Y$, Wiranto, Susilaningsih $N$. Pengaruh kombinasi vitamin $C$ dan $E$ dosis tinggi terhadap sistem hemopoetik penderita kanker kepala dan leher yang mendapat kemoterapi cisplatin. Jurnal Medica Hospitalia. 2012; 1(2): 89-94.

14. Zulkarnain AK. Perbedaan indeks massa tubuh (IMT) pasien ca mamae duktus infiltratif sebelum dan sesudah mendapat terapi neoadjuvant: Studi di RSUP Dr. Kariadi Semarang [Online]. 2010 [cited 2017 Juni 27]. p, 1-12. Available from: http://core.ac.uk/download/pdf/11 722156

15. Suryapratama SA. Karakteristik penderita kanker serviks di RSUP Dr. Kariadi Semarang. Jurnal Kedokteran. 2012;1(1):1-11.

16. Kementerian Kesehatan. Kondisi Pencapaian Program Kesehatan Anak 
Indonesia. Jakarta: Kementerian Kesehatan Rl; 2014.

17. Adipo S. Hubungan dukungan keluarga dengan tingkat kecemasan pasien yang menjalani kemoterapi di ruangan Anyelir RSUD Arifin Achmad Pekanbaru Provinsi Riau. Jurnal One Line Mahasiswa). 2015;2(1):777-785

18. Ang, Emily, Lim HL, Lim S. Nutrional risk of cancer patients receiving chemotherapy in the ambulatory care seting: a prospective study. Singapore Nursing Jurnal. 2012; 39(4):2-11.

19. Ayustaningwarno F. Pengaruh variasi pemberian snack bar ubi jalar kedelai hitam terhadap kadar superoksida dismutase (SOD) darah. Jurnal Gizi Indonesia. 2014; 3(1): 20-25.

20. Ambarwati WN. Efek samping kemoterapi secara fisik pasien penderita kanker servik [Online]. 2014 [cited 2017 Juni 27]. Available from: portalgaruda. org/article.php?article $=35679$ 8\&val $=426 \&$ title $=$ EFEK $\% 20$ SAMPING $\% 20$ KEMOTERAPI\%20SECARA $\% 20$ FISIK\%2 OPASIEN\%20PENDERITA\%20KANKER\% 20SERVIK. Prosiding seminar nasional dan internasional Universitas Muhamadiyah Semarang http://jurnal.unimus.ac.id/index.php/psn120 12010/article/view/1428

21. Hawkins R, Grunberg S. Chemotherapy induced nausea and vomiting: challenges and opportunities for improved patients outcomes. Journal of Oncology Nursing or the Oncology Nursing Society. Doi:10.118/09.CJON 2009; 13(1): 5-64.

22. Dian B. Hubungan penampilan makanan dan faktor lainnya dengan sisa makanan biasa pasien kelas 3 Seruni RS Puri Cinere Depok. Skripsi. Jakarta: Universitas Indonesia; 2012.
23. Nuryati P. Hubungan antara waktu penyajian, penampilan dan rasa makanan dengan sisa makanan pada pasien rawat inap dewasa di RS Bhakti Wira Tamtama Semarang [Online]. Skripsi. UNIMAS Digital Library Universitas Muhammadiyah Semarang, 2008 [cited 2017 Juni 27]. Available from: http://digilib.unimas.ac.id

24. Christian M. 2011. Pengolahan banana bars dengan inulin sebagai alternatif pangan darurat. Skripsi. Bogor: Fakultas Teknologi Pertanian Institut Pertanian Bogor, 2011. Bogor Crowther PC. 1979. The Processing of Banana Products for Food Use. Tropical Product Institute, London.

25. Widjanarko SB. Pengembangan prototipe pangan darurat berenergi tinggi dan padat nutrisi berbasis potensi bahan baku lokal (ubi jalar, jagung, kedelai, dan tepung porang). Laporan Project K3PT Litbang Pertanian. 2008.

26. Wiranata IGA. Formulasi dan Karakteristik Nutrimat Bar Berbasis Tepung Kacang Kedelai (Glycine Max. L) dan Tepung Kacang Merah (Phaseolus Vulgaris. L) Sebagai Makanan Pasien Kemoterapi. Skripsi. Badung: Program Studi IImu Gizi Fakultas IImu Kesehatan Sains dan Teknologi Universitas Dhyana Pura. 2017.

27. Uyami, Hendriyani $H$, Wijaningsih $W$. Perbedaan daya terima, sisa dan asupan makanan pada pasien dengan menu pilihan dan menu standar di RSUD Sunan Kalijaga Demak. Skripsi. Semarang: Jurusan Gizi Politeknik Kesehatan Kemenkes. 2014.

28. Hartono A. Asuhan Nutrisi Rumah Sakit. Yogyakarta: Penerbit Buku Kedokteran, 2000. 